\title{
Jelena Vignjević
}

Učiteljski fakultet Sveučilišta u Zagrebu

jelena.vignjevic@ufzg.hr

\section{Bernardina Petrović}

Filozofski fakultet Sveučilišta u Zagrebu

bernardina.petrovic@ffzg.hr

\section{Nepoznati Šulek: naučitelj odhranjivanja i obučavatelj čitanja}

Primljeno / received 5. 10. 2017. Prihvaćeno / accepted 12. 7. 2018.

DOI: $10.21066 /$ carcl.libri.8.1.1

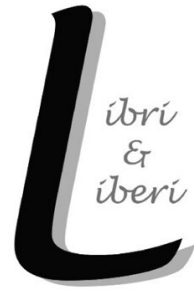

Bogoslav Šulek poznat je ponajprije kao jezikoslovac, leksikograf i publicist. U njegovu se radu posebno ističe prinos znanstvenomu nazivlju na hrvatskom jeziku, pa ga se naziva utemeljiteljem hrvatskoga znanstvenoga nazivlja. Međutim, slabo je i nedostatno razmatran Šulekov prinos didaktici kao općoj teoriji školskoga poučavanja i učenja, a napose metodici početnoga čitanja na hrvatskom jeziku, o čem se raspravlja u ovom radu. Bogoslav je Šulek naime 1850. u Zagrebu tiskom Franje Župana objavio Naputak za one, koji uče čitati i Malu čitanku za početnike. U tima dvjema knjižicama, prvoj namijenjenoj učiteljima i roditeljima, a drugoj učenicima, Bogoslav Šlek predstavlja tadašnjoj hrvatskoj školskoj javnosti novu metodu podučavanja čitanja - „Lautir-Methode“ - po kojoj se čitanje uči tako da se izgovara i pamti glas slova, a ne njegov naziv. Šulekov metodički priručnik i čitanka $\mathrm{u}$ ovom su radu sagledani u kontekstu onodobne metodike početnoga čitanja na hrvatskom jeziku, čime se pokazala njihova uloga prekretnice $u$ dotadašnjem načinu opismenjavanja.

Ključne riječi: Bogoslav Šulek, Mala čitanka za početnike, metodika početnoga čitanja, Naputak za one, koji uče čitati

Malo je poznato bavljenje Bogoslava Šuleka pedagogijom ili kako sam navodi „,naukom odhranjivanja“. O tome svjedoči i bilješka o njemu u Hrvatskoj enciklopediji. ${ }^{1}$

1 Šulek, Bogoslav (Bohuslav), hrvatski polihistor, jezikoslovac, publicist i prirodoslovac slovačkog podrijetla (Sobotište, Slovačka, 20. IV. 1816 - Zagreb, 30. XI. 1895). U Požunu (Bratislavi) završio je 1837. pravni i teološki studij. Zbog nagluhosti nije se zaredio, 1838. došao u Brod, naučio hrvatski i ostao u Hrvatskoj te se uključio potpuno u njezin politički i kulturni život. Počeo raditi 
Na pisanje o toj temi potaknulo ga je, piše u predgovoru Naputka za one, koji uče čitati (u daljnjem tekstu Naputak), stanje u onodobnom hrvatskom društvu: „Nauka odhranjivanja u obće slabo je jošte kod nas poznata, napose pako obučavanje u čitanju

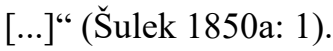

Kad Šulek objavljuje Naputak, 1850. godine, već je prošlo sedamdesetak godina od utemeljenja organiziranoga pučkoga školovanja u svim krajevima pod habsburškom vlašću, u duhu prosvjetiteljskih ideja Marije Terezije, a prema prvomu zakonu koji je uredio državno školstvo i na hrvatskom prostoru - Općem školskom redu iz 1774. (Cuvaj 1910b). Ipak, navodi Šulek (1850a: 1): ,[...] i ono malo školah koje imamo, tako polako napreduje. " Mnogi su razlozi tomu, od materijalnih preko kulturoloških do političkih, a ponajviše, barem što se opismenjavanja na hrvatskom jeziku tiče, činjenica da je u većini škola u Hrvatskoj i Slavoniji nastavni jezik njemački, a u Dalmaciji talijanski. Naime, samo su župne ili općinske škole imale mogućnost poučavanja na narodnom jeziku, dok se u državnim školama poučavalo na njemačkom odnosno talijanskom (prema Cuvaj 1910b i Munjiza 2009). Tek se od 1830. uvode narodne elementarne škole (dvogodišnje, općinske) na hrvatskom jeziku, a stanje s jezikom poučavanja znatnije će se početi mijenjati tek nakon 1847., odnosno nakon što Hrvatski sabor izglasa hrvatski za službeni jezik u Hrvatskoj, čime hrvatski ulazi u javnu uporabu, pa i u školstvo. Osim politike, takvo je stanje s nastavnim jezikom odredio i nedostatak učitelja obrazovanih na hrvatskom jeziku i za podučavanje čitanja hrvatskim jezikom te nedostatak školskih priručnika pisanih hrvatskim jezikom.

1839. u Zagrebu u tiskari, nastavio kao novinar i urednik, a zatim kao znanstvenik. Priključio se preporoditeljima 1841. U Rostocku je 1867. obranio doktorsku tezu na latinskom jeziku o R. Boškoviću (objavljena iste godine u Zagrebu pod naslovom M. R. J. Bošković, Disertatio inauguralis). Od 1866. bio je član JAZU, a njezin tajnik od 1874. do smrti. - Šulek je svojim djelom i golemom aktivnošću ostvario mnoge ideje narodnih preporoditelja o napretku kulture, znanosti i gospodarstva. Gotovo nema područja u kojem nije djelovao. Objavio je više od 200 naslova najraznovrsnije tematike. Bio je urednik najprestižnijih novina i časopisa (Danice 1843-46., Novina Horvatskih, Slavonskih i Dalmatinskih 1846-48., Slavenskoga juga 1849-50., Pozora 1865-66), utemeljitelj hrvatske publicistike. Njegov politički spis Šta naměravaju Iliri (1844) programska je osnova narodnoga preporoda među Južnim Slavenima. Nenadmašan je njegov prinos hrvatskomu znanstvenomu nazivlju: botaničkomu (Prirodopis za niže realne gimnazije, 1856; Biljarstvo za višje gimnazije, I-II, 1856-59), fizikalnomu (Prirodni zakonik za svakoga iliti popularna fizika: I. Silarstvo, 1873; II. Vesarstvo, 1875; III. Svjetlarstvo, 1876), kemijskomu (Lučba za svakoga ili popularna kemija, 1881), glazbenomu (Postanak i narav glasbe, 1875) te šumarskomu (Korist $i$ gojenje šumah, osobito u trojednoj kraljevini, 1866; knjiga napisana na molbu zemaljske vlade, radi populariziranja pošumljavanja a nakon velikih sječa koje su opustošile šume u Hrvatskoj). Uspješno je preveo s madžarskoga 12 vojnih knjižica (pravilnik, vježbovnik, naredbenik) te time stvorio hrvatsko vojno nazivlje. Značajno mjesto zauzimaju pravni tekstovi: Naše pravice. Izbor zakonah, poveljah i spisah znamenitih za državno pravo kraljevine dalmatinsko-hrvatsko-slavonske od g. 1202-1868. (1868), Hrvatski ustav ili konstitucija godine 1882. (1883). Jezikoslovne rasprave O dvoglascu ie (1854), Zašto izostavljamo e pred r-om u riečih n. p. krv? (1854) i Obrana ahavca (1864) imale su utjecaj na tadašnju pravopisnu normu. Njegov prijedlog da se dugi jat treba pisati dvoslovom ie, a kratki dvoslovom je (liepo mjesto) jedno je od glavnih obilježja hrvatske pravopisne tradicije. Šulek je u prvom redu velik leksikograf (Němačko-hrvatski rěčnik, I-II, 1860; Hrvatsko-njemačko-talijanski rječnik znanstvenoga nazivlja, I-II, 1874-75; Jugoslavenski imenik bilja, 1879). Stotine njegovih riječi i danas se upotrebljavaju. Među njima su najčešći slavenizmi (bohemizmi, slovakizmi), internacionalizmi i njegove novotvorenice. 
Državna naobrazba učitelja, presudna za razvoj školstva, u Hrvatskoj se tek usustavljuje sredinom 19. stoljeća: 1847. donesena je odluka za osnutak dvogodišnje (muške) učiteljske škole u Zagrebu, koja je kao muška Učiteljna učionica zagrebačka započela s radom 16. studenoga 1849. (prema Cuvaj 1910b). U Naputku se Šulek (1850a: 9) na to osvrće riječima:

Nu tko želi biti věšt i sposoban učitelj, trěba da se i sam uči i da si potrěbitu nauku pribavi. Kod nas to do sada nije bilo ni moguće, jer nismo imali škole za učitelje [...]. Sada već imamo doduše u Zagrebu takvu školu za učitelje, ili tako zvano učiteljište (praeparandiu), u kojem će se mladići za zvanje učitelja pripravljati [...]

U tim okolnostima školstva, podučavanje početnoga čitanja na hrvatskom jeziku ne događa se sustavno, pa ne čudi da je prema popisu iz 1869. kod nas pismenih muškaraca 23,19\%, a žena tek 11,09\% (prema Franković i sur. 1958).

Opismenjavanje u onodobnim školama metodički je oslonjeno na dugu tradiciju kršćanskoga opismenjavanja, tiskom zabilježenu od najstarije poznate hrvatske glagoljske početnice iz 1527. i prisutnu u svim bukvarima, psaltirima, azbukividnjacima, abecedarima, ABC knjižicama, knjižicama slovoznanja, imen knjižicama, šlabikarima, jednom riječju - početnicama. Bez obzira na to radilo se o početnom podučavanju čitanja glagoljice, ćirilice ili latinice, metoda je bila ista - sricanje slova. Kako pokazuje Šulekov Naputak, tom će se metodom sve do polovice 19. stoljeća podučavati čitanje.

Osim što opisuje i metodički razrađuje nov način početnoga čitanja na hrvatskom jeziku, uspoređujući ga s dotad zastupljenim načinom, Šulek se u Naputku osvrće i na sam fenomen pismenosti, ali i institucijskoga okvira u kojem se ona provodi, odnosno škole. Tako u Naputku Šulek donosi nov metodički koncept početnoga čitanja, ali i svoj didaktički i pedagoški koncept. Može se stoga reći da Šulekov Naputak nije samo naputak za početno čitanje, već i naputak za školovanje, obrazovanje i odgoj.

\section{Opis Naputka za one, koji uče čitati i Male čitanke za početnike}

Naputak prati Malu čitanku za početnike (u daljnjem tekstu Čitanka). ${ }^{2}$ Knjižice su dva zajedno uvezana, ali i zasebna djela. Naputak je otisnut na 40 stranica numeriranih arapskim brojkama. Započinje „Predgovorom“, a od 4. do 14. stranice nenaslovljeni je tekst o obrazovanju, školstvu, uvjetima za dobro školstvo i uvjetima za uspješno učenje čitanja. Od 15. do 40. stranice pod naslovom „Kako trěba učit čitati.“ sadržan je detaljan opis načina podučavanja, namijenjen učiteljima. Time Naputak ostvaruje ulogu, današnjom metodičkom terminologijom rečeno, metodičkoga priručnika za nastavnike. Naputak prati udžbeničke jedinice u Čitanki - ,zadaće“ od 1. do 16.

Čitanka ima arapskim brojkama numerirane 63 stranice. Izišla je i kao posebna knjiga (prema Cuvaj 1910a: 419). Udžbeničke jedinice nižu se od 1. do 39. Prvih deset jedinica ispod brojki kojima su naslovljene ima različitim znakovima prikazanu količinu koju ta brojka označuje (npr. $10 \S \S \S \S \S \S \S \S \S \S)$. Prvih 15 jedinica pod brojkom kojom su naslovljene ima većom veličinom slova otisnuto slovo/slova koja

${ }_{2}$ Faksimil Čitanke objavljujemo u rubrici Baština ovoga broja časopisa Libri \& Liberi. 
se u toj udžbeničkoj jedinici uče. Sve do 31. jedinice koriste se samo mala tiskana slova, a 32. udžbenička jedinica sadrži abecedni slijed hrvatskih latiničnih slova u dva reda - velikih i malih te su na kraju niza u zagradama slova Q q, X x, W w, Y y. Od 38. udžbeničke jedinice rabe se i velika tiskana slova, početnica prerasta u čitanku, tekstovi su sve dulji, a obimom najveća 39. jedinica sadrži molitve („Jutarnja“ i „Večernja“), poslovice, zagonetke, pjesme, pripovijetke. Zadnja je udžbenička jedinica o mjerenju vremena - sati (arapske i rimske brojke za označavanje), dani (nazivi dana), mjeseci (nazivi mjeseci), godina. Na kraju Čitanke je „Gradjanska ćirilica mala i velika.“ (azbučni niz malih i velikih ćiriličnih slova s latiničnom transkripcijom) te tri basne ćirilicom otisnute.

Sadržaj Čitanke odgovara onodobnoj praksi poučavanja u kojoj je opismenjavanje značilo ovladavanje pismom u čitanju i pisanju slova i brojki, u računanju, u gledanju na sat te u razumijevanju diobe vremena od sata do godine.

Jasna je autorova namjera po kojoj su ove dvije knjižice jedna cjelina, Naputak je namijenjen učiteljima, a Čitanka učenicima, početnicima u čitanju.

\section{Okolnosti nastanka Naputka za one, koji uče čitati i Male čitanke za početnike}

U Europi prve polovice 19. stoljeća sve je izraženije buđenje nacionalnih identiteta. Habsburška Monarhija sve teže održava centralizam, najviše zbog pritiska mađarskoga nacionalizma koji je nastojao Ugarsku pretvoriti u Mađarsku i latinski jezik zamijeniti mađarskim kao jedinim službenim jezikom. Tako je i hrvatski nacionalni prostor, Banska Hrvatska, pritisnut jakom mađarizacijom. Opiru se tomu sve jači Ilirci kojima se pridružio i Bogoslav Šulek te svojom političkom publicističkom aktivnošću i te kako aktivno sudjelovao u javnom životu. Ukazivao je na potrebu otpora svih naroda Ugarske, pa i Hrvata, rastućoj mađarizaciji. Prosvjećivanje naroda i podizanje škola vidio je kao najbolji način otpora mađarizaciji i kao način izgradnje nacionalnoga identiteta (Markus 2006).

Naputak za one, koji uče čitati i Malu čitanku za početnike Bogoslav Šulek objavio je 1850. godine. U Predgovoru Naputku piše (Šulek 1850a: 1): „[...] počeo sam već prije više godinah oko ove knjige raditi, sada pako, dobivši vremena, dovàršio sam dělce i nakanio se izdati ga na světlo." Vremena je Šulek dobio jer je politički režim u Habsburškoj Monarhiji, uveden nakon sloma revolucije 1848./49., prekinuo Šulekovu političku publicističku djelatnost. Zabranjen je izlazak Slavenskoga juga, kojemu je Šulek bio urednik i koji je zastupao autonomiju hrvatskoga naroda na temelju federalizacije Monarhije (Gostl 1996: 23). Iste su 1850. godine zabranjene i Jugoslavenske novine u kojima je Šulek bio glavni urednik. Tako se Bogoslav Šulek, onemogućen u publicističkoj, priklonio prosvjetnoj djelatnosti. No ne samo stoga već i, kako primjećuje Ivan Martinčić (1989: 17), zato što je uvjerenje o obrazovanju kao putu prosvjetljenja čovjeka i zajednice vrhovno načelo svega Šulekova pisanja. U predgovoru Naputku Šulek (1850a: 4) piše: „Svakoga pravoga slavenskoga rodoljuba poglavita je dužnost obrazovati narod; bez ovoga ni kud ni kamo." Upravo to - 
obrazovanje naroda - Šulek ističe kao cilj svoga osobnoga djelovanja pa predgovor završava riječima: „Ako sam ovim dělcem ogromni taj posao ikoliko podpomogao trud mi je dovoljno nagradjen“" (Šulek 1850a: 4).

\section{Naputak i Mala čitanka u kontekstu onodobne pedagoške i didaktičke misli}

„Odhranjivanje“ je pojam kojim Šulek označava područje svoga djelovanja kad piše o obrazovanju djece, posebno u početnom čitanju i pisanju. Danas se podučavanje početnoga čitanja i pisanja na hrvatskom jeziku svrstava u područje metodike nastavnoga predmeta Hrvatski jezik (više o odnosu pedagogije i metodike u Bežen 2008). No, u Naputku Šulek zahvaća područje znatno šire od današnjega razumijevanja metodike kao „znanosti o poučavanju nastavnoga predmeta“ (Bežen 2008). Šulek se u Naputku osvrće na način školskoga poučavanja uopće, dakle na didaktiku kao teoriju nastave uopće (Bežen 2008: 65), ali i na odgoj djece u širem smislu, dakle na pedagogiju kao znanost o odgoju i obrazovanju. Pojam „odhranjivanje“ on razumijeva kao odgoj pa možemo „nauku odhranjivanja“ kojom započinje Predgovor Naputku, razumjeti kao pedagogiju, a „odhranjivanje“ kao pedagoški rad. Šulek (1850a: 14) napominje da se i sam ,jednoč takodjer bavio odhranjivanjem děce.“ To je bilo 1837. kada je nakon završenoga filozofsko-pravnoga i teološkoga studija pomagao bolesnomu ocu obavljajući svećeničke, pa i učiteljske poslove (prema Martinčić 1989: 16).

Šulekovo poimanje obrazovanja i odgoja utemeljeno je na kršćanskom duhu i liberalnim idejama europskoga 19. stoljeća. Kao liberal on podupire narodno prosvjećivanje, posebno prosvjećivanje seljaka, te rast građanskoga društva i njegovih institucija - institucija vlasti, kulturnih institucija, školskih ustanova i sl. Tako je za Bogoslava Šuleka obrazovanje djelatnost prosvjećivanja naroda, oplemenjivanja čovjekova uma i srca te zalog boljega života. Šulek (1850a: 5) svoje stavove ovako tumači:

U staro vrěme znalo je vàrlo malo ljudih čitat i pisati [...] a narod je čamio u gluposti i neznanstvu: pa glupi narod nemože nikada uživati prave srěće i slobode, jer je ni nepoznaje [...]. Nu malo po malo počele su jasne zrake sunca nauke sve dublje prodirati [...]. Tako se je světlo nauka sve bolje širio, a carstvo neznanstva sve je dublje propadalo. Time su ljudi očevidno postajali pametniji, bolji, bogatiji, jednom rěčju srětniji. Najposlě je do toga došlo, da su počeli i prosti seljaci knjigu učiti, jer su mudri kraljevi uviděli, da je laglje upravljati narodom razumnim, nego glupim, i da je ona zemlja najsilnija i najbogatija, u kojoj ima najviše pametnih ljudih. Zato su ovakvi mudri vladaoci gledali, da se u svakom selu škola zavede, i sada ima već zemaljah, gdě mal da ne svaki seljak znade čitat i pisati. Kolika to srěća za ovakve ljude!

Šulek se zalaže za obrazovanje dostupno svima i obrazovanje za sve. On iznosi žaljenje što se ne provodi takva ideja (Šulek 1850a: 7-8): ,[...] zato je već prije několiko godinah izišla mudra zapověd, da mora svaki otac děcu svoju u školu pošiljati; nu zapověd ova ostala je žalibože ponajviše samo na papiru." Zato se Šulek (1850a: 8) obraća i roditeljima: 
Pustite ju (djecu, op. a.) vi samo u školu, da štogod nauči, da si pamet i sàrce oplemeni: a ona će vam onda još većju korist doněti, još bolju pomoć dati. Děte, koje se u školi kako valja uvěštilo, bit će pokornije i poslušnije, ljubit će trud i posao, štovat će otca i majku, běžat će od pijanstva i lěnosti, poboljšat će vam gospodarstvo.

U kontekstu obrazovne tradicije na koju se nadovezuje, Šulekova misao o obrazovanju počiva na obrazovnim konceptima koji čine temelje europskoga obrazovanja, od pedagoških misli rimskoga retoričara Kvintilijana (oko 35. - oko 96.) preko Jana Amosa Komenskoga (1592. - 1670.) do Johanna Heinricha Pestalozzija (1746. - 1827.). Od Kvintilijana (prema Kvintilijan 1985) Šulek nasljeduje ideju školovanja kao odgoja i obrazovanja s nakanom formiranja čestita, plemenita i skladna čovjeka opremljena intelektualnima i moralnima vrijednostima. Kao i Kvintilijan i Šulek pridaje iznimnu važnost upravo početnoj, osnovnoj, nastavi na putu do takva čovjeka. Birajući sadržaje koje će učenici na početku obrazovanja čitati i na kojima će učiti o moralu i čestitu životu, Šulek slijedi Kvintilijanovu preporuku da to budu mudre izreke: „mudrih izreka sjećamo se i u starosti, jer ono što nam se utisne u pamet dok je još neoblikovana, doprinijeće izgradnji karaktera" (Kvintilijan 1985: 51) pa njegova Čitanka obiluje mudrim izrekama.

Jana Amosa Komenskoga - protestantskoga biskupa, pedagoga, znanstvenika, pisca - čija je Velika didaktika (Didactica magna, 1657.) bila u ono doba temelj pedagoškoga mišljenja - Šulek je nedvojbeno poznavao i uvažavao. Šulek temelji svoj nastavni koncept na načelima zornosti i postupnosti koje je Komenski (prema Komenski 1900) u Velikoj didaktici postavio za osnovna načela nastave, a dalje ih je razrađivao Johann Heinrich Pestalozzi, švicarski pedagog i reformator obrazovanja. Pestalozzi posebno razrađuje načelo zornosti smatrajući (prema Zaninović 1988) da spoznaja započinje s osjetnim doživljajem i dijete će lakše spoznati neku apstraktnu pojavu doživi li je sa što više osjetila. Tako i Šulek - predstavljajući novu metodu poučavanja početnoga pisanja, ali i govoreći o poučavanju općenito, naglašava važnost načela zornosti (Šulek 1850a: 16-17):

Ovo je tako zvano nazorno obučavanje (Anschauungs-Unterricht), to jest, štogod děca uče, to trěba da mogu viděti i zrěti. To je sasvime naravski put i zato su ga se svi pametni učitelji poprimili. [...] Děte nauči najlaglje ono, što mu dira u osěćala (Sinnesorgane), u sluh, vid, žmak itd. [...] Na ovo trěba osobito paziti kod děce i onda, kad ju učimo čitati: trěba joj staviti pismena pred oči i uši. Ovo je temelj ovoga moga naputka ili methode.

Šulek uza zorno poučavanje ističe i važnost postupnoga poučavanja:

1. načelom od poznatoga prema nepoznatomu (Šulek 1850a: 17-18):

$\mathrm{Nu}$ ovo nije samo kod děteta, nego i kod razborita već čověka: i mi svi najlaglje razuměmo i dokučujemo koji predmet, kada nam se pred oči i uši stavi, ili barem kad nam se prispodobi s kojom poznatom stvarju. [...] ja sam dakle nastojao [...] da glas svake litere prispodobim s kakvim glasom dětetu već poznatim, i da sliku svakoga pismena takodjer prispodobim s poznatom mu stvarju. Tako n. p. $c$ glasi onako kao cvrčanje cvèrčka: $c-c-c-c$; a izgleda onako kao càrv. Ja prispodabljam sliku ili figuru 
pismena s kakvom poznatom stvarju, koja se s istom literom počimlje; n. p. figura pismena $c$ prispodablja se $\mathrm{s}$ takvom stvarju, koja je spodobna istoj literi $c$ (naime $c$ àrv) i koje se ime počimlje s pismenom $c$ to jest: $c$ àrv.

2. načelom od lakšega prema težemu (Šulek 1850a: 10):

Dobra čitanka trěba da [...] naprěduje od lakoga k težjemu, jer je to put naravski. [...] Naše čitanke i abecedari neuče abecedu naravnim načinom, nestupaju od lagljega $\mathrm{k}$ težjemu, već priobćuju abecedu navadnim, nu slučajnim, za učenje nespretnim redom, naime: $a, b, c, \check{c}, d$ itd. Pa svaki će razboriti čověk priznati, da se děte laglje može naučiti $u$, koji ovdě stoji na koncu, nego $b$, koji je taki na početku.

U Naputku Šulek često predloženi put poučavanja argumentira putem prirode (,naravskim putem“), kao i Komenski kojemu je priroda uzor i model svakoga poučavanja te, na koncu, kao i Kvintilijan (1985: 26) koji u poučavanju savjetuje: „Upravimo svoje poglede na prirodu i nju slijedimo!“ (Naturam intueamur, hanc sequamur!)

U skladu s Pestalozzijem (prema Zaninović 1988: 158), koji naglašava da u metodici materinskoga jezika treba polaziti od dječjega govora i da ga treba razvijati, i Šulek ističe važnost razvijena govora u djece (Šulek 1850a: 15-16):

Ako mu (učitelju, op. a.) pako roditelji dovedu u školu sasvime zapuštenu děcu [...]. Ovakva děca ponajviše neznaju ni čestito hoditi, sěděti i govoriti [...]. Nijedno děte neće moći naučit čitati, ako ne zna govoriti, trěba dakle što više obogatiti njegovu pamet [...]. Tako n. pr. neka se s njim učitelj razgovara o kući, šta se sve u kući nalazi, kako se te stvari zovu, čemu su, tko jih je napravio; zatim neka prodje na opravu, na česti těla čověčjega, na vàrt (bašču) itd.

Šulek (1850a: 9-10) nasljeduje onodobnu pedagošku misao i u isticanju važnosti dobra i sposobna učitelja:

Ako hoćemo da škola postigne svoj cilj, trěba pàrvo da dobije sposobna i věšta učitelja, koji se je dao na taj posao ne od nevolje, nego iz ljubavi prema stališu učiteljskomu. Mnogi se doduše stide ovoga stališa, nu nije valjda daleko vrěme, kad će biti ovaj stališ pèrvi u zemlji, kad će se učitelji smatrati kao najveći dobrotvori naroda; jer istinu govoreć, od njih zavisi više srěća zemlje nego od poglavarah i zakonah. [...] Věština i prikladnost učitelja pàrvi je dakle uvět i potrěba, ako želimo da nam naše pučke škole procvate $[\ldots]$.

I napokon, Šulek nasljeduje velike didaktičare i u isticanju važnosti čitanke kao osnovnoga nastavnoga sredstva koje služi opismenjavanju i stoji na početku školovanja: ,[...] a drugi je uvět dobra Čitanka ili Abecedar. Ni najvěštiji težak neće moći s dèrvenom ili tupom motikom kopati; ni najpametniji učitelj neće iz hàrdjave knjige bàrzo naučiti děcu štiti““ (Šulek 1850a: 10).

\section{Šulekov metodički rad u kontekstu onodobne hrvatske prakse školskoga poučavanja}

Pedagoške i didaktičke ideje Bogoslava Šuleka postaju jasne i otkrivaju svoj potpuni smisao tek postavljene u kontekst obrazovne stvarnosti hrvatskoga prostora 
i vremena u kojem su pisane, kao i u kontekst onodobne obuke u čitanju hrvatskoga jezika. Šulekova (1850a: 1) zamjerka da je: ,nauka odhranjivanja u obće slabo jošte kod nas poznata $[\ldots]$ “ " posve je razumljiva jer unatoč tomu što praksu organiziranoga školovanja na hrvatskom prostoru možemo pratiti još od 9. stoljeća, tj. od početka prisutnosti benediktinaca među Hrvatima (Cuvaj 1910a; Munjiza 2009), razvoj pedagoške teorije možemo pratiti tek od polovice 19. stoljeća. Istina, u dugu periodu kršćanskoga poučavanja nastale su i vrijedne misli o odgoju, koje su pisali Petar Pavao Vergerije (1370. - 1444.), Marko Marulić (1450. - 1524.), Matija Vlačić Ilirik (1520. - 1575.), Franjo Petrić (1529. - 1597.), Nikola Gučetić (1549. - 1610.) i one čine najstariju podlogu za hrvatsku pedagošku misao (prema Lukaš i Munjiza 2010). No, puno će još vremena proći do cjelovitoga i sustavnoga promišljanja odgoja i obrazovanja u Hrvatskoj. Onima koji su se u hrvatskim školama bavili odgojem i obrazovanjem dostupna su bila djela europskih pedagoga i didaktičara u izvornicima. Uz već spomenute, na čitavom je području Monarhije bio uvažavan metodički priručnik za učitelje - Methodenbuch für Lehrer der deutschen Schulen in den $k$. $k$. Erbländern - čiji je autor slovački pedagog Ignaz Johann von Felbiger (1724. - 1788.). To je djelo, prvi put objavljeno 1774. te poslije višekratno objavljivano u prerađenim ili skraćenim izdanjima uglavnom bez oznake autora, bilo izvor pedagoškoga znanja i za hrvatske učitelje sve do sredine 19. stoljeća (prema Franković i sur. 1958: 60). Naime, postojao je prijevod toga djela na hrvatski, nazvan Methodus, i njime su se služili učitelji sve do objavljivanja knjige Znanost odhranjivanja za porabu učiteljskih sěmeništah. Ta je knjiga tiskana u Budimu 1849. (prema Cuvaj 1910b) za potrebe obrazovanja učitelja Učiteljne učionice zagrebačke koja je 1849. započela s radom. Knjiga je prevedena s mađarskoga, a donosi: „temeljnu znanost odhranjivanja (pedagogia fundamentalis)“, „kućevno odhranjivanje u obće“ $\mathrm{i}$ „,̌kolsko odhranjivanje u obće.“ Potom se opisuju tri područja odgoja: „tjelesno odhranjivanje“, „duševno odhranjivanje“ te „ćudoredno odhranjivanje.“ Na kraju je poglavlje o samoodgoju ili „,izobražavanju samoga sebe.“ Iste su 1849. u Budimu otisnute još dvije knjige pedagoškoga sadržaja, također prevedene s mađarskoga: Posebna znanost podučavanja, ili naputak $k$ uspěšnom predavanju pojedinih naukah (Didactica specialis) i Obćenita znanost podučavanja (Didactica generalis) (prema Cuvaj 1910b: 418).

Šulek sam navodi da piše Naputak upravo da bi popunio prazninu u pedagoškoj literaturi na hrvatskom jeziku, posebno za one učitelje koji su već u nastavnoj praksi i ne mogu se vratiti na preparandiju (Šulek 1850a: 9-10):

Sada već imamo doduše u Zagrebu takvu školu za učitelje, ili tako zvano učiteljište (praeparandiu), u kojem će se mladići za zvanje učitelja pripravljati i učiti kako jim valja s děcom baratati (postupati), kako u čitanju i pisanju, u računstvu i drugih naukah obučavati: ali šta da čine sadašnji učitelji, koji se nemogu više u školu ovu povratiti? - Ova knjižica olakšat će jim podobro njihov mučni posao, ako se po njoj povedu.

Jesu li knjige objavljene u Budimu 1849. bile Šuleku pri ruci, nije poznato. No po mnogim podudarnostima moguće je zaključiti da je Šulek svoje misli o pedagogiji i općoj didaktici temeljio na istim izvorima na kojima se temelje i pedagoški priručnici 
iz Budima. Za ilustraciju mogu poslužiti njegove misli o nužnosti dobra odnosa učitelja prema učenicima (Šulek 1850a: 15):

Děca, koja pàrvi put $\mathrm{u}$ školu dolaze, il su posve smutjena, te vide u učitelju samo čověka, koji ima pravo kaštigovat jih, zato ga se plaše i neusude se pogledati mu u oči, a kamo li s njim govoriti. U ovom slučaju mora učitelj ponajprije da si njihovu ljubav pribavi. Ovo će postići, ako se bude s njimi razgovarao, šalio i koješta zabavnoga jim pokazivao i pripovědao, dok jim ovako dokaže, da škola i učitelj nisu baš onako odurne stvari, kao što mnoga děca misle. Děca, ako se bude s njimi dobro baratalo, sprijateljiti će se na skorom s prijatnim učiteljem, te će jim škola omiliti, a oni će ju s radostju polaziti.

To je gotovo podudarno s mislima iz Znanosti odhranjivanja za porabu učiteljskih sěmeništah (1849: 72-73):

Děca većinom, prie nego će u školu poći, boje se škole i mèrze ju kao kakvo město od mučenja. [...] Uspěh kako odhranjivanja tako i podučavanja mnogo visi od toga, ako učitelj s děcom, koja počinju u školu hoditi, znade postupat tako da děca uvide, da je škola posve drugčie město, nego što su ona odprie mislila. [...] Pervi dani neka prodju u raznih razgovorih o poznatih predmetih, koji su dětetu ugodni. [...] Za razumnoga učitelja važna je stvar, da steče ljubav i pověrenje svojih pitomacah.

No metodiku čitanja opisanu u priručniku Posebna znanost podučavanja, ili naputak $k$ uspěšnom predavanju pojedinih naukah (Didactica specialis) (1849) Šulek odbacuje i donosi pred hrvatske učitelje nov način obuke u čitanju.

\section{Šulekov metodički rad u kontekstu onodobne metodike početnoga čitanja}

Šulekovim knjižicama za početno čitanje prethodi duga praksa podučavanja čitanja, od najstarije hrvatske početnice iz 1526. pa do niza početnica u prvoj polovici 19. stoljeća. Tijekom vremena mijenjali su se tekstovi koje se čitalo, no ne i način učenja čitanja. Početnice koje su služile za podučavanje čitanja u vjerskim školama podučavale su čitanje na vjerskim tekstovima, pa su istovremeno bile i mali katekizmi. Početnice koje nastaju u 18. i 19. stoljeću za potrebe državnoga školstva donose tekstove općih moralnih načela i sadržaja bliskih djeci - o svakodnevici, hrani, dijelovima tijela, djeci, braći, prijateljima, roditeljima, životinjama, biljkama... Prva je takva (prema Cuvaj 1910b) početnica za hrvatski jezik objavljena 1779. u Budimu - ABC knisicza za potrebnozt narodnih skol. Ta je početnica kajkavski prijevod njemačke početnice službeno propisane za upotrebu u pučkim školama u Ugarskoj i Hrvatskoj za cara Josipa II. - ABC oder Namenbüchlein, zum Gebrauche der Nazionalschulen in dem Königreiche Ungarn. Ista je njemačka početnica 1783. otisnuta, također u Budimu, u štokavskom prijevodu - ABC iliti knjixica slóvoznánja za potribu národnih ucsiónicah u Kraljestvu Slavonie i koristila se u Slavoniji od 1779. do 1851.

Osim te latinične početnice, koja je doživjela niz izdanja, do Šulekove su početnice u školama bile prisutne i brojne druge knjižice za početno čitanje hrvatskoga latinicom. Npr. (prema Cuvaj 1910b) na hrvatskom prostoru još su se koristile: Imen 
knjisica za haszen ladanzkih uchilnic Horvatzkoga Orszaga, Knjixica slovoznanja za potribu narodnih ucsionicah u C. K. Slavonsko Srimskoj kraini, Chtenya kniga od pravotvornozti za potrebuvanye narodnih shkol Vugerzkoga y Horvatzkoga Kralyeztva. U prostoru Vojne krajine koristili su se: Abecedar za děcu, sastavljen po Imbri Antoliću i Abecedar za potrěbu narodnih učionicah u Hérvatskoj i Slavonii a napose za Vojničku krajinu. Za Primorje i Dalmaciju u Trstu je objavljivana Imeno-knjixica za seoske uçionice, a u Zadru Knjixica imenah za seoske uçionice po cesaro-kraljskim derxavama (prema Cuvaj 1910b). Sve su te početnice započinjale obuku čitanja predstavljanjem abecednoga slijeda latiničnih slova, najprije samoglasnika potom suglasnika, i svih kombinacija suglasnika sa samoglasnicima. Nakon toga su vježbe čitanja koje se postupno usložnjuju - od čitanja jednosložnih riječi, dvosložnih riječi, višesložnih riječi, skupova riječi, rečenica do teksta. Na te se početnice referira Bogoslav Šulek (1850a: 13) kad piše da: „naprěduje kod nas čitanje račjim korakom, a děca dàrktju kad samo čuju da moraju učit štiti.“

Onodobno učenje čitanja, od pomisli na koje djeca dršću, poznato je kao sricanje slova, šlabikuvanje ili šlabekuvanje, ${ }^{3}$ odnosno (u Šulekovu tekstu) šlabekovanje. Mendeš (2009: 120) opisuje tu metodu ovako:

Ovom metodom slova se uče abecednim redom iz zidnih tabli ili zidnih početnica. Svako je slovo imalo svoje ime. Čitanje se uči sricanjem. Kad bi dijete zastalo, moralo je ponoviti cijeli postupak. Učenik bi upoznao ime slova mehaničkim putem. Za djecu je ova metoda bila izuzetno teška pa su protiv nje progovorili J. A. Komenski, Pestalozzi i J. J. Rousseau (koji je naziva „bič djetinjstva“).

Iako je još Kvintilijan (1985: 49) iskazao neslaganje s načinom podučavanja slova „po kojem djeca prije uče nazive i red slova nego njihov oblik“ i savjetovao „da u isto vrijeme uče i naziv i oblik slova, kao što čine kada su u pitanju ljudi“, sricanje se održalo sve do sredine 19. stoljeća. Da je takva praksa učenja čitanja i u hrvatskim školama prve polovice 19. stoljeća, svjedoči i priručnik za čitanje objavljen u Budimu 1843. - Chtenya kniga od pravotvornozti za potrebuvanye narodnih shkol Vugerzkoga y Horvatzkoga Kralyeztva (1843: 11): „Chteje Vuchenik krivo, tak more on Rech onu, koju krivo je chtel, preshlabekuvati, i taki nato prechteti.“

Istu praksu sricanja preporučuje i priručnik iz Budima 1849. Posebna znanost podučavanja ili naputak $k$ uspěšnom predavanju pojedinih naukah (Didactica specialis) koji do čitanja vodi sricanjem i „slovkovanjem“( (slogovanjem). O redu pri upoznavanju slova, o imenovanju slova, o sricanju i o slovkovanju taj priručnik navodi:

Najbolje je, ako se nauk ovaj počme s poznavanjem samoglasnikah [...]. Poslě ovih slěde suglasnici po redu, kao što su na abecednoj tablici naznačeni. $O$ imenovanju suglasnikah različita su mněnja. Tako žele nekoji, da se poradi jednoličnosti izgovaraju svi suglasnici sa $e$, n. pr. $b e, c e, d e, f e$, le, me itd. Akoprem se ovo osuditi baš nemože,

3 Rječnik hrvatskoga ili srpskoga jezika (1961: 693):

ŠLABEKUVANJE - n. nom. verb. od šlabekuvati. U Bjelostjenčevu rječniku (slabekuvańje syllabizatio).

ŠLABEKUVATI - šlabekujem. impf. sricati. U rječniku Habdelićevu (syllabizo) i u Bjelostjenčevu (šlabekujem, syllabizo). 
zato ipak, čini nam se, potrěbito nije; jer děte će isto tako lako i naučiti i izgovarati el kao što i le. A k tomu valja děte věžbati, da se nauči izgovarati suglasnike u savezu sa svimi samoglasnici kako sprěda tako i straga, na pr. : la, le, li, lo lu, al, el, il, ol, ul. (Posebna znanost... 1849: 4).

Sricanje onda se stopram ima započeti, kad su se učenici već sasvim dobro naučili poznavati i imenovati slova (Posebna znanost... 1849: 12).

Slovkovanje najprěči je i najsigurniji prijelaz k čitanju. Děca pojedina slova bèrzo u sebi imenuju, a zatim cělu slovku glasno i razgovetno izgovore (Posebna znanost... 1849: 21).

Ako već znadu rěči od dvě i više slovkah dosta bèrzo i věšto izgovarati, neka predje na čitanje (Posebna znanost... 1849: 22).

Dakle, tako su prema važećemu priručniku za metodiku čitanja poučavani budući učitelji u zagrebačkoj učiteljskoj školi.

Šulek $(1850 a: 11,12)$,šlabekovanj“" opisuje ovako:

Svatko se dan danas smije, kad čuje, kako su odprije obučavali děcu u staroslavenskoj azbuki. Ondě se pismena zovu: az, buki, vědi, glagolj, dobro itd., pa su onda ovako učili sricati ili šlabekovati: buki $a z=b a, b u k i$ iže $=b i$ itd. Nu je li sadašnji način šlabekovanja kod nas mnogo pametniji? - Děca se nauče poznavati pismena $\mathrm{i}$ izgovarati, ne njihov pravi glas nego samo njihovo ime, to jest: $a, b e, c e, d e, e, e f, g e$, $h a$ itd. A kad to s velikom mukom nauče, eto ti nove běde! Trěba šlabekovati. Děte ima šlabekovati rěč rok. Ono govori: er-o-ka; učitelj će mu kazati, neka sad sve skupa na jedanput izgovori. Děte će naravski kazati: eroka; nu jok vala! Učitelj će mu reći, da valja kazati: rok, dakle izpustiti polovicu glasovah koje biaše děte naučilo kod poznavanja literah. Koliko to bezumlje!

Umjesto toga, Šulek u Naputku zagovara, opisuje i detaljno tumači nov način učenja čitanja metodom glasanja - „Lautir-Methode“-i ističe: „Kod ovog naputka neima da kako ni tako zvanoga šlabekovanja, već se děte odmah uči štiti“ (Šulek 1850a: 20).

Valja napomenuti da je bilo kritike metode sricanja i prije Šulekova Naputka. Još je Adolfo Veber Tkalčević u raspravi „Nešto za učitelje početnih učionicah“ objavljenoj u Danici 1847. na str. 85. kritički pisao o sricanju i osvrnuo se na nove metode koje se primjenjuju drugdje u svijetu (prema Cuvaj 1910b: 326). I preparandijski priručnik za metodiku čitanja (Posebna znanost podučavanja, ili naputak $k$ uspěšnom predavanju pojedinih naukah 1849: 11) bio je svjestan neslaganja pojedinih pedagoga i didaktičara s uporabom metode sricanja, ali je ipak na njoj ustrajao: „Akoprem mnogi osudjuju: odbacuju sricanje kao věžbanje neugodno, bezkoristno, gdě se vrěme uzalud samo troši; mi ćemo ga ipak u školah naših zadèržati.“

\section{Podučavanje čitanja metodom glasanja (koju Šulek zagovara)}

Metoda početnoga čitanja o kojoj Šulek piše, nova je hrvatskomu školstvu, a njome se još od 1802., tj. od godine objavljivanja početnice Handfibel oder Elementarbuch zum Lesenlernen nach der Lautirmethode, koriste u drugim zemljama, o čemu piše Šulek (1850a: 12): 
Nu u drugih zemljah, po imenu u Njemačkoj, Francezkoj, zabacili su već onaj opaki način obučavanja, te se dàrže tako zvane Lautir-Methode, po kojoj děte mora izgovarati $r$ kao $r-r$ - $r$, a ne kao er itd. Samo je kod nas jošte sve kod staroga.

Tu je novu metodu početnoga čitanja osmislio bavarski reformator školstva, protestantski teolog i pedagog, Nijemac Heinrich Stephani (1761. - 1850.). Stephani je kao pedagog i didaktičar elementarnoga poučavanja isticao potrebu napuštanja dotadašnje metode sricanja slova i osmislio je fonetsku, odnosno glasovnu metodu početnoga čitanja - njem. Lautiermethode.

Ta se metoda početnoga čitanja današnjom metodičkom terminologijom naziva metoda glasanja, a opisuje se kao učenje čitanja pri kojem se (Mendeš 2009: 121):

[...] razlikuju: glas, znak, ime. Učenici su najprije upoznavali slova, ali ih nisu izgovarali posebnim nazivima, kako je bio slučaj pri sricanju, nego glasovima. Učitelj bi za vrijeme čitanja prekrio drugo slovo (glas) pa se na taj način odvijalo čitanje. Učenici izgovaraju (glasaju) prvo slovo (glas) sve dok učitelj ne otkrije drugo slovo (glas) i tada spajaju drugo slovo (glas) s prvim.

I sricanje i glasanje sintetičke su metode početnoga čitanja jer se polazi od elemenata govora i pisma - glasova i slova, te ih se povezuje u veće cjeline - slogove, riječi, rečenice i tekst (usp. Bežen 2004).

Šulek kao osnovne značajke „Lautir-Methode“ spominje sljedeće:

1. Svako slovo (,pisme“"4 lat. litera) ima svoj glas, svoj znak (,sliku“, lat. figura) i svoj naziv (,,b se zove be; k se zove $k a$; m zove se $e m ; \mathrm{j}$ zove se jot itd.“ [Šulek 1850a:11]). Jasno se razlikuju glas i slovo: „Svako pisme (litera) ima svoj glas kojim se izgovara, i sliku (figuru) koja se piše“" (Šulek 1850a: 18).

2. Izgovara se samo glas slova, ne njegov naziv. Šulek (1850a: 19) objašnjava: „Děca se neuče izgovarati suglasnice (consonantes) sa glasnicom, nego se samo čisti pravi glas pismena takvoga izgovara. Tako n. p. pisme $m$ neizgovara se kao em nego samo kao $m-m-m$, t. j. ono mumljanje."

3. Najprije se uče samoglasnici potom suglasnici, u skupinama kako se slažu u riječi. Taj naputak Šulek (1850a: 29-30) donosi ovako:

Neka se (učitelj, op. a.) uvěri da svi njegovi učenici poznaju glasnice, pa onda neka prodje na suglasnice. [...] kazat će jim, da dva ili više pismenah, kad se na jedanput izuste, to se zove slovka (syllaba). Uč.: Pročitaj mi sad bàrzo jednu (slovku, op. a.) za drugom. Děte će najposlě kazati mama. [...] Uč.: [...] sada već znate dvě slovke štiti, to jest jednu čitavu rěč.

4. Slova se slikovito pamte. „Ja prispodabljam sliku ili figuru pismena s kakvom poznatom stvarju, koja se s istom literom počimlje“ (Šulek 1850a: 18). Još se Komenski zalagao za učenje slova pomoću slike, tj. da se djetetu svako slovo vizualizira slikom životinje ili predmeta naziv kojih počinje slovom koje se uči, odnosno za, današnjom terminologijom rečeno, fonografičku metodu (usp. Bežen 2004, 2008). Tako i Šulek (1850a: 20) predlaže da učitelj upozori djecu kako je malo tiskano slovo $o$ slično

4 Šulek (1850a: 17) napominje: „Pisme, pismena (kao sěme, sěmena) znači litera; a pismo, pisma, to je scriptum, Schrift. Ove dvě rěči dobro trěba razlikovati.“ 
obruču, $i$ igli, $u$ izgleda kao dva uha, $e$ kao pogrbljena starica (Evica), $c$ kao crv, $a$ kao aždaja, $m$ kao most, $r$ kao rudo na kolima itd. (Šulek 1850a: 20):

Trěba dakle osobito nastojati da dětetu živo predstavimo sliku svakoga pismena, da mu je tako opišemo, kako izgleda, da dětetu uvěk kao pred očima trepti, i kad ga upitaš kako izgleda $c$, da ti zna na pamet kazati, da je $c$ sličan càrvu.

Tako se, tumači Šulek, djeluje na sva djetetova osjetila, uči se zorno, olakšava se učenje postupnošću od jednostavnijega k složenomu, a sve u nakani „da Bog dade, te urodilo istim plodom, kojim biaše urodilo u drugih zemljah slično nastojanje, da se i kod nas učenje čitanja prestane smatrati kao zlostavljanje i maltretiranje, i da postane prava zabava“" (Šulek 1850a: 19-20).

Šulekova Mala čitanka za početnike udžbenik je za školsko podučavanje početnoga čitanja uporabom metode glasanja („Lautir-Methode“). U njoj su jezičnometodički predlošci, tj. tekstovi zasićeni jezičnom pojavom koju učenici upoznaju i usvajaju. Metodički instrumentarij, tj. tekst kojim se učenika vodi do spoznaje željenih pojmova i procesa (prema Bežen 2008), autor donosi u Naputku dajući prijedlog primjene metode glasanja u nastavnoj praksi. Tako Naputak ispunjava ulogu metodičkoga priručnika namijenjena učiteljima (,onima koji uče čitati“), on je objašnjenje za primjenu metode koju Bogoslav Šulek zagovara kad je riječ o podučavanju čitanja.

\section{Metodičke i sadržajne odlike Male čitanke za početnike}

1. Učenici započinju čitanje malim tiskanim slovima. S velikim se tiskanim slovima upoznaju tek u 32. udžbeničkoj jedinici, nakon usvojenoga čitanja malim tiskanim slovima.

2. Prvo se čitaju samoglasnici potom suglasnici, ovim slijedom: $o, i, u, e, a ; m, r$, $v, s, \check{s}, c, \check{c}, z, \check{z}, j, g, p, b, h, k, f, n, n j, d, d j, l, l j, t, t j, \check{e}, d \check{z}, \grave{c}$. Slova se grupiraju prema načelu sličnosti i mogućnosti kombiniranja u slogove i riječi.

3. Već od usvajanja prvoga suglasnika djeca čitaju riječi („mama, ime“), a od usvajanja drugoga suglasnika čitaju skupove riječi (,mera ore“) i rečenice („maria ima maramu“"), a po usvajanju svih slova djeca čitaju tekst (o prihvatljivom dječjem ponašanju) (Šulek 1850b: 13):

[...] nevalja děci simo tamo po ulici ili sokaku trkati i vikati, do konja ili vola hoditi, hrvati se i tući, učitelja i roditelje srditi. kada se děca uče, neka nelupaju nogama, neka nebiju i negrde ine učenike. děca imaju paziti na učitelja kada govori, pa učiti čitati, pisati i računati. ako nebudu tako činila, neće dobiti oběda ni večere.

4. Iz jedne udžbeničke jedinice u drugu usložnjuje se sintaktička zahtjevnost metodičkih predložaka - u riječima se postupno povećava broj slogova, u rečenicama broj riječi, u tekstovima broj rečenica.

5. U svima su udžbeničkim jedinicama metodički predlošci otisnuti tako da su slogovi u riječi međusobno odvojeni manjom bjelinom, a riječi i rečenice većom. Tek su metodički predlošci na kraju čitanke (poslovice, zagonetke, pjesme i pripovijetke) tiskani standardnim slogom s bjelinom samo među riječima i rečenicama. 
6. Metodički predlošci za prva slova koja se uče čitati $(o, i, u, e, a, m)$ otisnuti su najvećom veličinom slova, za sljedeća su slova $(r, v, s, \check{s}, c, \check{c}, z, \check{z}, j, g, p, b, h)$ metodički

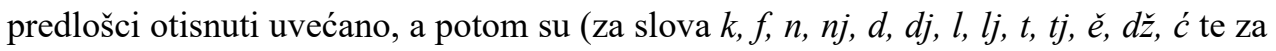
sve ostale udžbeničke jedinice) otisnuti standardnom veličinom slova.

7. Sadržaji koje djeca čitaju odnose se na neposredno dječje iskustvo, iz dječjega su svijeta, događaju se djeci i služe djeci. Poučna je nakana itekako u sadržajima prisutna, bilo da je odgojna - npr. „nikomu se nezaměri“ (Šulek 1850b: 9), bogoštovna - npr. „ufamo se u boga“ (Šulek 1850b: 9) ili obrazovna - npr. ,žito se sije a kada dozori onda se žanje“ (Šulek 1850b: 11). Pri osvrtu na sadržaj metodičkih predložaka, zamjetan je velik broj tekstova koji potiču djecu na čuvanje zdravlja, npr. „kada bosonogo děte trči i nepazi, može se nabiti i dobiti ranu. rana boli i mora se lěčiti“" (Šulek 1850b: 13-14); „ko cukor (šećer) ljubi, svi će mu izpasti zubi“ (Šulek 1850b: 20) i dr. Prvi među duljim tekstovima (većima od jedne rečenice) upućuje djecu da ljube roditelje i da im budu poslušna, a drugi tekst donosi nagovor protiv pijenja vina i pijanstva. Uočljivo je višekratno ponavljanje upozorenja da se vino i rakija ne smiju piti. Mnoge su pojedinačne i izdvojene misli o tom, npr. ,nevalja piti rakiju“ (Šulek 1850b: 16) kao i tekst (Šulek 1850b: 21-22):

[...] ako si žedan, nepi vina nego ladnu vodu, najbolja je za děcu voda, a vino děci Škodi, děte pijuće vino postati će glupo i bedasto, dobit će svakojake grde bolesti ili betege, bit će siromašno. zato mila děco nepite vina ni žganice ili rakije, nego poslušajte mene i pite vodu, pa ćete biti pametni i jaki, nećete morati ležati u postelji ili krevetu, nećete imati u starosti velik crven nos nego lěpo rumeno lice, svaki će vas čověk poštovati i ljubiti, vi nećete biti siromašni i imat ćete sve što vam trěba. a kada postanete stari i dobijete sědu kosu ili vlasi, onda ćete kazati, fala bogu, ne postadoh u mladosti pijanac, zato sam sada jošte živ, a drugi, koji su pili vino i rakiju, već su u zemlji zakopani.

Po sadržajima o štetnosti pijenja vina i rakije Šulekova se početnica izdvaja od dotadašnjih početnica koje su slijedile sadržajne zadanosti, ne odmičući se puno od početnice iz 1779. i obraćajući se djeci s nagovorima o bogobojaznosti, pristojnosti, poslušnosti, marljivosti, urednosti i sl. Druga tema koje se Šulek u Čitanki često dotiče jest tema krađe. Česta su upozorenja djeci da ne kradu. Na primjer (Šulek 1850b: 25): „ostavi na miru ono, što nije tvoje, i ako si něšto uzeo, što je tudje, odmah to povrati, inače bi te svaki čověk za kradljivca ili tata držao" ili dulji tekst (Šulek 1850b: 56, 57):

Budući Luka još děte, hotio je većkrat što uzeti svojoj sestri. Ona bi ga kresala po pèrstih i rekla bi mu: Ovo je moje! Kad je on mislio, da mu je něko sviralicu uzeo, reče ona: Je li ti to drago? Dakle ni ti nesměš nikomu ništa uzeti. Jedno dva put su materi uzmanjkale někoje male stvari. Ona je oštro istraživala, i našla jih je medju Lukinimi igračkami. Odmah ga prisili, da stvari tamo postavi, gdě jih je bio uzeo. Udari ga zatim šibom oštro po rukah, i reče mu: Neuzimaj ništa, što nije tvoje. Ako to još jednom učiniš, još ću te oštrije kaštigovati. Tim načinom naučio se je Luka u ranoj dobi, da se nesmě ništa tudjega uzimati.

Po zastupljenosti poruka djeci da se čuvaju pijanstva i krađe može se zaključiti da je te probleme Šulek uočavao kao nevolje društava za koje je pisao Čitanku. Po 
tom je njegova Čitanka sadržajem usklađena s vremenom i prostorom za koji je pisana. Obraćajući se djeci navedenim porukama, Šulek u Čitanki donosi sadržaje koji su podloga za ostvarenje onoga što je najavio u Naputku (1850a: 8) obraćajući se roditeljima: „Děte, koje se u školi kako valja uvěštilo, bit će pokornije i poslušnije, ljubit će trud i posao, štovat će otca i majku, běžat će od pijanstva i lěnosti, poboljšat će vam gospodarstvo.“

Kako bi svim učenicima kojima se obraća osigurao i stvarno razumijevanje teksta, Šulek se obilno koristi kontaktnim sinonimima, uvažavajući tako jezično iskustvo djece govornika različitih regionalnih inačica hrvatskoga jezika. Neki od primjera jesu:

- u budžaku ili kutu je batina (Šulek 1850b: 12)

- běla džigerica je zato da ljudi mogu dihati a zove se inače pljuća (Šulek 1850b: 12)

- tata vozi drva iz šume, da naloži ili zakuri (Šulek 1850b: 13)

- sěnokoša ili livada daje nama sěno i otavu (Šulek 1850b: 16)

- kada děte štogod zla učini, onda je u veliku strahu, jer se boji da će ga otac ili mati strogo i oštro kazniti tojest kaštigovati (Šulek 1850b: 23)

- mlinar melje šenicu i tako čini od nje melju ili brašno (Šulek 1850b: 23).

U konačnici, Šulekova Čitanka ima sve one odlike za koje se autor zalaže kad piše o dobroj čitanki u Naputku (Šulek 1850a: 10, 13):

Dobra čitanka trěba da bude spisana jezikom dětinjoj naravi priměrenim; da naprěduje od lakoga k težjemu, jer je to put naravski; da je sve razgovětno i razumljivo; da se děluje ne samo na pametovanje (memoria) nego i na um [...]

Čitanka trěba nadalje da u sebi zadàrži samo zabavne ili zabavno-koristne stvari, a ne kojekakve mudrolije, nepristupne dětinjoj pameti [...]

Najposlě čitanka trěba da bude povećjimi slovi štampana, a ne sitnimi. [...] jer ni odrasli čověk nemože tako lasno razlučiti dvě sitne stvari kao dvě velike.

\section{Životni put Šulekovih knjižica}

Svi su učitelji sa Šulekovim knjižicama bili upoznati, što potvrđuje Antun Cuvaj: „Da se olakoti obučavanje u čitanju, priredio je god. 1850. Bogoslav Šulek knjižice: Naputak za one, koji uče čitati te knjižicu Mala čitanka za početnike“ (Cuvaj 1910b: 419) uz bilješku: „Ovu je knjižicu bansko vijeće dalo štampati, te o zemaljskom trošku razdijeliti među pučke učitelje, jer bi im pored njihove malene plaće teško bilo kupovati tu knjigu“ (Cuvaj 1910b: 419).

Šulekovoj Maloj čitanki vrijeme nije bilo sklono. Školska godina 1851./1852. bila je prva u vremenu Bachova apsolutizma (31. prosinca 1851. - 20. listopada 1860.). Reformirano je školstvo, provodila se germanizacija, školske su se knjige otiskivale isključivo u Beču, a sve su škole i učitelji podvrgnuti crkvenomu nadzoru (prema Cuvaj 1910c). Ivan Martinčić (1989) detaljno opisuje okolnosti neprihvaćanja Šulekove čitanke u školskoj praksi. U Vojnoj je krajini odbačena odlukom Stručnjačke konferencije u Petrinji 1850. na kojoj je među inima sudjelovao i tada školski ravnatelj, autor početnice Abecedar za děcu, Imbro Antolić. On se usprotivio uporabi Šulekove 
Čitanke s argumentom da „Lautir-Methode“ nije propisana u važećoj metodičkoj literaturi i da se stoga ne smije upotrebljavati. U Banskoj Hrvatskoj stigla je 1851. službena zabrana uporabe Šulekove Čitanke u školama. Biskup Haulik bio je protiv toga da „akatolički“ pisac sastavlja knjige za katoličku mladež, a biskup Strossmayer smatrao je da Šulekova knjiga „politizira“ (prema Martinčić 1989: 22). Nameće se zaključak kako je djelo o kojem je riječ odbačeno zbog autora, ne zbog djela samoga.

Iako su metodički unaprijedili praksu početnoga učenja čitanja, Šulekovi su nastavni priručnici ubrzo zaboravljeni, kao i njegov ukupan prinos hrvatskomu školstvu i pedagogiji. Da taj prinos nije valoriziran napominje i Ivan Martinčić (1989: 15) potkrjepljujući stav člankom „Bukvari (Početnice)“ u Enciklopediji Jugoslavije, koji u prikazu početnica u Hrvatskoj „od početnica iz 1771, 1779. i 1796. prelazi odmah na početnicu iz 1878.“

Isto se može kazati i za današnji trenutak. Malo se zna o ulozi Bogoslava Šuleka u kontinuitetu opismenjavanja na hrvatskom jeziku. Pogledamo li danas u Hrvatskoj enciklopediji članak „Početnica“, pedagoško-metodičku osnovu početnica nema Bogoslava Šuleka. Prvi se navodi Stjepan Basariček (1848. - 1918.) koji je djelovao kao pedagog 80-ih godina 19. stoljeća, a priručnik za početno čitanje i pisanje objavio je više od četrdeset godina nakon Šulekova Naputka. Na kraju, pored priznanja za cjelokupan rad u području školskoga poučavanja, Bogoslavu Šuleku dugujemo priznanje i za samu riječ početnica ${ }^{6}$ u značenju knjige iz koje se što počinje učiti.

\section{Zaključak}

Pedagoške i didaktičke ideje Bogoslava Šuleka, iskazane u djelu Naputak za one, koji uče čitati najavile su ono što će tek doći-Zakon o pučkim školama i preparandijama iz 1874. Taj je zakon prvi hrvatski školski zakon o obveznom obrazovanju, zakon kojim hrvatski jezik postaje nastavni jezik, normiraju se nastavni predmeti u pučkim školama,

5 Početnica, prva dječja školska knjiga; udžbenik namijenjen učenicima prvoga razreda osnovne škole za početno čitanje i pisanje. Početnica svojim sadržajem, ilustracijama, grafičkom opremom i metodičkom artikulacijom, prilagođenima dobi prvoškolaca, nastoji učenje učiniti pristupačnim i zanimljivim. Suvremena početnica oblikovana je kao višeizborni sklop teksta, slike, aplikacije, filma, kasete, CD-a i dr. kao metodičke cjeline za učenje čitanja, pisanja i jezičnoga izražavanja. Neke škole, kao npr. alternativna Waldorfska, ne upotrebljavaju klas. udžbenike, pa ni početnice, već u njima početnica nastaje kao radni materijal tijekom nastave. U strukturiranju i izradbi početnice polazi se od službenoga nastavnoga plana i programa, jezičnih sadržaja, metode, redoslijeda i načina obradbe glasova, slova i govornih cjelina. Pozornost se posvećuje i različitim komunikacijskim vještinama, interkulturalnim sadržajima i računalnim programima. Pritom se moraju uzimati u obzir razvojne mogućnosti učenika te kulturni i intelektualni kontekst sredine. U nas su prve početnice nastale u duhu crkv. knjiga za vjerske škole (Anton Dalmatin, S. Konzul Istranin). Tek se s pojavom svjetovnih škola može govoriti o početnici kao o udžbeniku, a tada se javljaju i stručnjaci koji osmišljavaju njezin sadržaj i pedagoško-metodičku osnovu (S. Basariček, Z. Špoljar, T. Ivkanec, I. Filipović, F. Baf, Rudolf Saršon, V. Cvitan, E. Vajnaht, Josip Baričević, Lucija Puljak).

${ }^{6}$ U Rječniku hrvatskoga ili srpskoga jezika JAZU (1928) stoji:

PÒČÊTNICA, fem. prema masc. početnik. [...] - b) kńiga, iz koje se što počińe učiti. Između rječnika samo u Šulekovu ńem.-hrv. (Anfangsbuch) [...] 
prava i dužnosti učitelja, nadležnih upravnih tijela i Crkve (Gaćina Škalamera 2014: 107). Šulek je u Naputku zagovarao upravo to - obvezno obrazovanje za svu djecu, hrvatski kao nastavni jezik, vrijednost i važnost učitelja.

U ovom radu navedeni primjeri pokazuju da je Bogoslav Šulek svoja razmišljanja o obrazovanju i poučavanju, te o podučavanju početnoga čitanja na hrvatskom jeziku, izgradio uvažavajući stavove velikih pedagoga i klasika pedagoške misli, ali i sebi suvremenih pedagoga i metodičara.

Metoda glasanja („Lautir-Methode“) koju je u podučavanju početnoga čitanja predstavio Bogoslav Šulek u djelima Naputak za one, koji uče čitati i Mala čitanka za početnike prekinula je višestoljetnu tradiciju opismenjavanja sricanjem, a nastavna praksa početnoga čitanja koja je uslijedila nakon toga pokazuje da je Šulekov utjecaj na podučavanje početnoga čitanja bio izniman. Različitim će se metodama koristiti buduće hrvatske početnice, ali će uvijek polaziti od glasova (usp. Marjanović 2001), a metoda glasanja ostala je, u pojedinim elementima, $i$ do danas prisutna u početnom čitanju. Može se stoga kazati da je Šulekov metodički rad bio prekretnica u praksi opismenjavanja u Hrvatskoj.

Šulekov prinos hrvatskomu školstvu uopće, a posebno podučavanju čitanja, vrijedan je i značajan, no ne i dovoljno istražen. Istraživačima u području metodike početnoga čitanja na hrvatskom jeziku tek predstoji njegovo opisivanje, analiziranje i vrjednovanje. Ovaj je rad prilog tomu.

\section{Popis literature}

Basariček, Stjepan. 1892. Rukovođ za početnicu i bukvar. Zagreb: Tisak i naklada knjižare Lav. Hartmana.

Bežen, Ante. 2004. Sintetičke metode u nastavi početnog čitanja i pisanja. Metodika 5 (1): 32-47.

Bežen, Ante. 2008. Metodika - znanost o poučavanju nastavnog predmeta. Zagreb: Učiteljski fakultet i Profil.

Chtenya kniga od pravotvornozti za potrebuvanye narodnih shkol Vugerzkoga y Horvatzkoga Kralyeztva. 1843. Budim. Cuvaj, Antun. 1910a. Građa za povijest školstva kraljevinā Hrvatske i Slavonije od najstarijih vremena do danas. Svezak II. Zagreb: Tisak Kr. zemaljske tiskare.

Cuvaj, Antun. 1910b. Građa za povijest školstva kraljevinā Hrvatske $i$ Slavonije od najstarijih vremena do danas. Svezak III. Zagreb: Tisak Kr. zemaljske tiskare.

Cuvaj, Antun. 1910c. Građa za povijest školstva kraljevinā Hrvatske i Slavonije od najstarijih vremena do danas. Svezak IV. Zagreb: Tisak Kr. zemaljske tiskare.

Franković i sur. 1958. Povijest školstva i pedagogije u Hrvatskoj. Zagreb: Pedagoškoknjiževni zbor.

Franković, Đuro. 2013. Prve hrvatske Početnice (abecevice, bukvari). $<$ http://zornicanova.hu/ prve-hrvatske-pocetnice-abecevice-bukvari-1/>, $<$ http://zornicanova.hu/prve-hrvatske -pocetnice-abecevice-bukvari-2/> (pristup 12. veljače 2017.).

Gaćina Škalamera, Sonja. 2014. Zakon o pučkim školama i preparandijama u kraljevinama Hrvatskoj i Slavoniji iz 1874. godine: Sto četrdeseta obljetnica hrvatskoga zakona o obveznom obrazovanju. Anali za povijest odgoja 13: 99-133. 
Gostl, Igor. 1996. Bogoslav Šulek, otac hrvatskoga znanstvenoga nazivlja. Radovi Leksikografskoga zavoda „Miroslav Krleža“, knj. 5: 9-58.

Hrvatska enciklopedija, mrežno izdanje. 2017. Leksikografski zavod Miroslav Krleža. $<$ http://www.enciklopedija.hr/Natuknica.aspx?ID=48876> (pristup 31. ožujka 2017.).

Komenski, Ivan Amos. 1900. Velika didaktika. Preveo iz latinskoga dr. Julije Golik, gimn. profesor. Zagreb: Naklada Hrv. pedagoško-književnoga zbora.

Kvintilijan, M. F. 1985. Obrazovanje govornika. Sarajevo: Veselin Masleša.

Lukaš, Mirko i Emerik Munjiza. 2010. Pedagoška hrestomatija - izbor tekstova hrvatskih pedagoga. Osijek: Filozofski fakultet, Sveučilište J. J. Strossmayera u Osijeku.

Marjanović, Barka. 2001. Pristupi početnom čitanju i pisanju u starijim hrvatskim početnicama. Metodika 2 (2-3): 75-85.

Markus, Tomislav. 2006. Publicistika kao poziv: Bogoslav Šulek u javnom životu Hrvatske 1842. - 1867. Časopis za suvremenu povijest 39 (1): 181-204.

Martinčić, Ivan. 1989. Školski udžbenici i priručnici Bogoslava Šuleka (prethodna pitanja uz njihovo vrednovanje). U: Zbornik za povijest školstva i prosvjete, ur. Dragutin Franković, sv. XXII, 15-39. Zagreb - Beograd - Ljubljana: Hrvatski školski muzej Pedagoški muzej - Slovenski šolski muzej.

Mendeš, Branimir. 2009. Početna nastava čitanja i pisanja - temelj nastave Hrvatskoga jezika. Magistra Iadertina 4 (4): 116-130.

Munjiza, Emerik. 2009. Povijest hrvatskog školstva i pedagogije. Osijek: Filozofski fakultet Sveučilišta Josipa Jurja Strossmayera u Osijeku i Hrvatski pedagoško-književni zbor, ogranak Slavonski Brod.

Posebna znanost podučavanja, ili naputak $k$ uspěšnom predavanju pojedinih naukah (Didactica specialis). 1849. Budim: Tiskarnica kralj. ugar. Mudroučne skupštine.

Rječnik hrvatskoga ili srpskoga jezika. 1961. Sv. 73. Prir. Stjepan Musulin. Zagreb: Jugoslavenska akademija znanosti i umjetnosti.

Rječnik hrvatskoga ili srpskoga jezika. 1928. Sv. 43. Prir. Tomo Maretić. Zagreb: Jugoslavenska akademija znanosti i umjetnosti.

Šulek, Bogoslav. 2017. Hrvatska enciklopedija, mrežno izdanje. Leksikografski zavod Miroslav Krleža. <http://www.enciklopedija.hr/Natuknica.aspx?ID=59993> (pristup 31. ožujka 2017.).

Šulek, Bogoslav. 1850a. Naputak za one, koji uče čitati. Zagreb: Tisak Franje Župana.

Šulek, Bogoslav. 1850b. Mala čitanka za početnike. Zagreb: Tisak Franje Župana.

Zaninović, Mate. 1988. Opća povijest pedagogije. Zagreb: Školska knjiga.

Znanost odhranjivanja za porabu učiteljskih sěmeništah. 1849. Budim: Štamparija Kralj. sveučilišta. 


\section{Jelena Vignjević}

Faculty of Teacher Education, University of Zagreb, Croatia

\section{Bernardina Petrović}

Faculty of Humanities and Social Sciences, University of Zagreb, Croatia

\section{The Unknown Bogoslav Šulek: An Educator and Methodologist of Initial Literacy}

Bogoslav Šulek is recognised as a linguist, lexicographer and publicist. His lexicological work earned him the title of father of Croatian scientific terminology. However, his work in didactics as a general theory of school teaching and learning, and in the teaching methodology of initial reading in Croatian, has not yet been adequately researched. This part of Sulek's work is the subject of the current article, in particular two books that he published in Zagreb in 1850: Naputak za one, koji uče čitati [Instructions for Those Who Are Learning to Read] and Mala čitanka za početnike [A Little Reader for Beginners]. In them, Šulek presented a new method of initial reading - the "Lautir-Methode", or phonics. With this method, reading is taught so that the sound of the letter is pronounced, not its name. When Šulek's books are considered in the context of the didactics of initial reading skills at that time, we can conclude that they were a turning point in the history of the methodology of teaching literacy in Croatian.

Keywords: Bogoslav Šulek, Mala čitanka za početnike, Naputak za one, koji uče čitati, teaching methodology of initial reading 